\title{
Aplikasi Manajemen Barang Reject Berbasis Android (Studi Kasus PT. Schneider Electric Manufacturing Batam)
}

\author{
Muhammad Nashrullah ${ }^{1 *}$, Niken Aprilia Harefa ${ }^{2}$ \\ 1,2 Jurusan Teknik Informatika, Politeknik Negeri Batam, Batam \\ 1,2 Jln. Ahmad Yani Batam Kota, Kota Batam, 29461, Kepulauan Riau, Indonesia \\ email: ${ }^{1}$ nashrullah@polibatam.ac.id, ${ }^{2}$ niikenaprilia@gmail.com
}

Copyright $@ 2019$, Politeknik Harapan Bersama, Tegal

\begin{abstract}
PT. Schneider Electric is leading the digital transformation of energy management and automation in homes, buildings, data centers, infrastructure and industries. PT. Schneider is one of the companies that applies the technology applied to the work process, one of the Debug Manager systems, which is a system used to reject items in the line area, but it still has weakness in inputting product data when it read by users with a small text its make debug manager or LI (Line Inspector) often entered the wrong data, and there is no procedure that allows the debugging process of items that refuse to do research on the existing system. The research conducted at PT. Schneider Electric Manufacturing Batam was conducted to repair the Debug Manager system in PT. Schneider, this research was conducted with the waterfall method starting with conducting interviews with the operator or LI (Line Inspector) Debug Manager then proceeding with the application design (Design) which is then implemented, verified until maintenance is carried out. Reject Management Application based on android, which is an application that scans QR code on labels, and text that uses products on a smartphone or tablet and can also give debugging technicians notification. The debugging process can be done well.
\end{abstract}

Abstrak - PT. Schneider Electric Manufacturing adalah perusahaan yang terdepan dalam Transformasi Digital Manajemen Energi dan Otomatisasi di Rumah, Gedung, Pusat Data, Infrastruktur, dan Industri. PT. Schneider salah satu perusahaan yang menerapkan teknologi berdasarkan perkembangannya terhadap proses kerja perusahaan, salah satunya sistem Debug Manager, yaitu sistem yang digunakan untuk mengatasi barang yang reject di area line, namun sistem tersebut masih memiliki kekurangan dalam penginputan data tipe produk dimana bacaan tersebut ditulis dengan tulisan yang kecil, sehingga operator debug manager atau LI (Line Inspector) sering sekali memasukkan data yang salah, dan tidak adanya notifikasi untuk teknisi debug yang melakukan proses debug barang yang reject sehingga perlu dilakukan penelitian terhadap sistem yang ada. Penelitian yang dilakukan di PT. Schneider Electric Manufacturing Batam ini dilakukan untuk memperbaiki sistem Debug Manager yang ada di PT. Schneider, penelitian ini dilakukan dengan metode waterfall dimulai dengan melakukan wawancara dengan operator atau LI (Line Inspector) Debug Manager kemudian dilanjutkan dengan perancangan aplikasi (Design) yang kemudian di implementasikan, diverifikasi hingga dilakukan maintenance. Adapun Aplikasi Manajemen Barang Reject yang dibuat berbasis android, dimana aplikasi mampu melakukan pemindaian $Q R$ code pada label, dan text yang berukuran kecil pada produk menggunakan kamera pada perangkat smartphone ataupun tablet dan juga dapat memberikan notifikasi kepada teknisi debug sehingga proses debug dapat dilakukan dengan baik.

Kata Kunci - barang reject, aplikasi manajemen, memindai text, memindai $Q R$ Code.

\section{PENDAHULUAN}

PT. Schneider Electric Manufacturing Batam adalah salah satu perusahaan yang berada di Batam, perusahaan ini terdepan dalam Transformasi Digital Manajemen Energi dan Otomatisasi di Rumah, Gedung, Pusat Data, Infrastruktur, dan Industri. Perusahaan ini telah menggunakan teknologi dengan baik untuk mempercepat kinerja perusahaan dan perusahaan ini juga sangat memperhatikan kualitas produk yang dihasilkan, dengan meminimalisir kerugian dari barang atau produk yang rusak atau reject dengan mendaur ulang atau memperbaiki produk tersebut sehingga dapat digunakan kembali. Proses memperbaiki barang atau produk reject di PT.Schneider Electric dikenal dengan istilah Debug Manager, proses ini berbasis web dan dilakukan oleh operator line, operator debug, dan teknisi debug. Namun, sistem Debug Manager berbasis web tersebut, masih memiliki kekurangan, operator Debug Manager (LI) dan teknisi debug mengalami permasalahan dalam pengisian data reference dikarenakan tulisan yang ada pada produk begitu kecil, memasukkan data barang reject yang juga dilakukan oleh teknisi debug dan proses debug yang mengalami keterlambatan dikarenakan perbaikan dapat dilakukan setelah LI selesai memasukkan data barang reject, penggunaan perangkat komputer secara bergantian membuat pengelolaan barang reject menjadi kurang efisien. Berdasarkan permasalahan yang ada, maka sistem aplikasi manajemen barang reject berbasis android diusulkan, sistem ini menggunakan platform android studio. Aplikasi manajemen barang reject ini akan digunakan pada tablet atau smartphone yang disediakan oleh perusahaan, untuk memanajemen data barang reject.

Metode penyelesaian aplikasi manajemen barang reject berbasis android ini menggunakan metode waterfall, yang diawali dengan pendekatan secara sistematis dari mengumpulkan kebutuhan sistem melalui wawancara dengan operator debug manager lalu dilanjutkan dengan tahap menganalisa, melakukan pembuatan desain, coding, kemudian dilakuan pengujian dan tahap maintenance.

*) penulis korespondensi: Muhammad Nashrullah

Email: nashrullah@polibatam.ac.id 


\section{PENELITIAN YANG TERKAIT}

Sebelumnya telah dilakukan penelitian mengenai aplikasi manajemen barang reject berbasis android yang dilakukan oleh Fathonah, Trisma Nur dkk (2016) [1] meneliti mengenai pengembangan fitur retur dari sistem informasi persediaan barang", dimana penulis menambahkan fitur retur dari sebuah sistem informasi persediaan barang. Penelitian selanjutnya dilakukan oleh Sepantri, R (2007) [2] terkait denan sistem informasi pengolahan barang return pada PT. LGEIN cabang Semarang, pada penelitian ini dibuat sebuah sistem informasi pengolahan barang return menjadi hasil barang inspeksi. Penelitian selanjutnya dilakukan oleh Sukamdana, Boegi (2011) [3], meneliti perancangan sistem informasi inventory berbasis web pada PT. Citra Gemilang Prima.

Berdasarkan penelitian yang telah dilakukan, pada penelitian dalam artikel ini dibuat sebuah sistem informasi inventori berbasis web dan sebagai perbandingan antara sistem yang telah dibuat dengan sistem yang akan dibuat dapat dilihat pada tabel 1 .

TABEL I

PERBANDINGAN SISTEM

\begin{tabular}{|c|c|c|c|c|}
\hline $\begin{array}{l}\text { Pemban } \\
\text { ding }\end{array}$ & $\begin{array}{l}\text { (Trisma, } \\
\text { 2016) [1] }\end{array}$ & $\begin{array}{c}\text { (Boegie, } \\
\text { 2011) } \\
{[3]}\end{array}$ & $\begin{array}{c}\text { Rino, } \\
\text { 2007) } \\
{[2]}\end{array}$ & $\begin{array}{c}\text { (Niken, 2018) } \\
\text { Yang } \\
\text { diusulkan }\end{array}$ \\
\hline Platform & $\begin{array}{l}\text { Tidak } \\
\text { Dijelaskan }\end{array}$ & HTML & PHP & Android Studio \\
\hline Database & $\begin{array}{l}\text { Tidak } \\
\text { Dijelaskan }\end{array}$ & MySQL & MySQL & MySQL \\
\hline Fitur-fitur & $\begin{array}{l}\text { Menu login, } \\
\text { form barang, } \\
\text { form transaksi } \\
\text { pembelian } \\
\text { dan } \\
\text { penjualan, } \\
\text { data retur dan } \\
\text { laporan }\end{array}$ & $\begin{array}{l}\text { Menu } \\
\text { barang } \\
\text { stok } \\
\text { awal, } \\
\text { menu } \\
\text { barang } \\
\text { retur, } \\
\text { menu } \\
\text { transaksi. }\end{array}$ & $\begin{array}{l}\text { Menu } \\
\text { login, } \\
\text { Menu } \\
\text { utama, a, } \\
\text { warehous } \\
\text { e, service } \\
\text { dan } \\
\text { manager }\end{array}$ & $\begin{array}{l}\text { Menu login, } \\
\text { Registrasi, Form } \\
\text { pemindaian } Q R \\
\text { Code dan Text, } \\
\text { form input data, } \\
\text { notifikasi, } \\
\text { dashboard }\end{array}$ \\
\hline $\begin{array}{l}\text { Tempat } \\
\text { Penerapa } \\
\mathrm{n}\end{array}$ & $\begin{array}{l}\text { Toko Bahana } \\
\text { Elektric }\end{array}$ & $\begin{array}{l}\text { PT.Citra } \\
\text { Gemilang } \\
\text { Prima }\end{array}$ & $\begin{array}{l}\text { PT. LG } \\
\text { Electroni } \\
\text { cs } \\
\text { Indonesia }\end{array}$ & $\begin{array}{l}\text { PT. Schneider } \\
\text { Electric } \\
\text { Manufacturing } \\
\text { Batam }\end{array}$ \\
\hline
\end{tabular}

\section{METODE PENELITIAN}

\section{A. Bahan Penelitian}

Data yang diperlukan dalam melaksanakan dan mengimplementasikan Aplikasi Manajemen Barang Reject Berbasis Android ini meliputi data-data yang berhubungan dengan data barang reject di PT. Schneider Electric Manufacturing Batam. Data-data tersebut dihasilkan dari wawancara dengan karyawan-karyawan yang berkaitan.

\section{B. Kebutuhan Sistem}

Sistem atau platform yang digunakan untuk membangun aplikasi manajemen barang reject ialah android studio [4] dengan versi Android 6.0.1 Marshmallow [5], [7] dengan memanfaatkan localhost dari XAMPP [8], [9]. Perancangan aplikasi manajemen barang reject dilakukan dengan UML, berupa usecase, class diagram, sequence diagram, dan ERD [10], [11].

\section{Kerangka Pemikiran}

Pada Gbr. 1 menggambarkan alur dari penelitian yang sudah dilakukan.

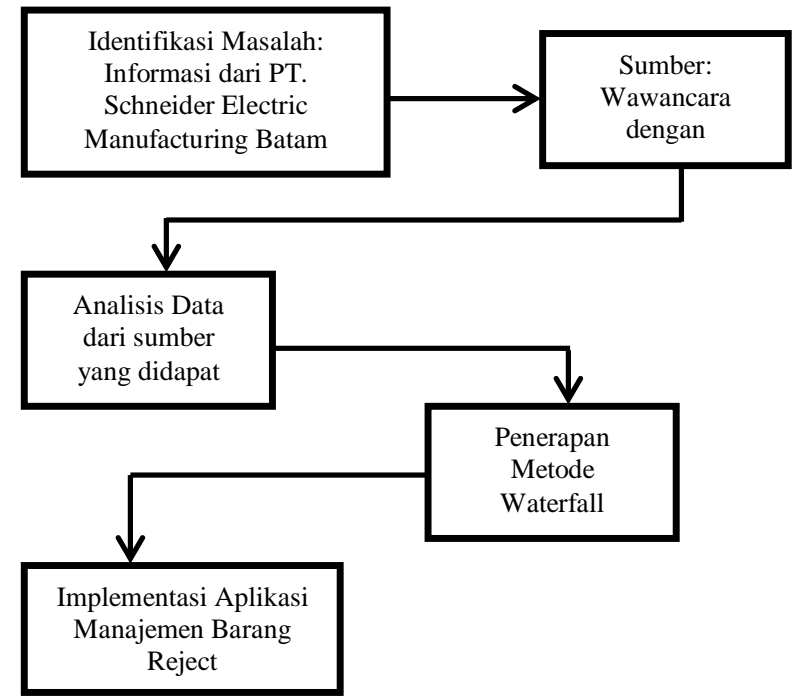

Gbr.1 Kerangka Pemikiran

\section{Deskripsi Umum Sistem}

Ilustrasi Deskripsi Umum Aplikasi Manajemen Barang Reject Berbasis Android digambarkan seperti Gbr 2. Deskripsi Umum SIstem.
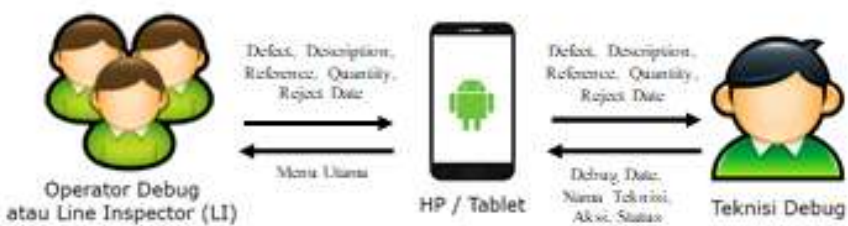

Gbr. 2 Deskripsi Umum Sistem

Pada Gbr. 2 menjelaskan bahwa aplikasi manajemen barang reject digunakan oleh dua pengguna (user) yaitu operator dan teknisi debug, operator debug dapat memasukkan data dengan melakukan pemindaian $Q R$ Code yang ada pada barang reject, dan memberikan notifikasi kepada Teknisi, kemudian data tersebut diperbaharui oleh teknisi debug.

\section{HASIL DAN PEMBAHASAN}

Dalam perancangan sebuah aplikasi, maka diperlukan analisa terhadap kebutuhan-kebutuhan yang diperlukan untuk membangun Aplikasi Manajemen Barang Reject.

A. Kebutuhan Fungsional

- F001 Pengguna dapat mendaftar ke aplikasi

- F002 Pengguna dapat masuk ke aplikasi

- F003 Pengguna dapat memindai QR Code

- F004 Pengguna dapat memindai text

- F005 Pengguna dapat memasukkan data barang reject

- F006 Pengguna dapat memperbaharui data barang reject

- F007 Pengguna dapat menghapus data barang reject

- F008 Pengguna dapat mencari data barang reject

- F009 Pengguna dapat melihat data barang reject 
- F010 Pengguna dapat memberikan notifikasi

- F011 Pengguna dapat keluar dari aplikasi

\section{B. Hak Akses User}

Berdasarkan kebutuhan-kebutuhan fungsional yang ada, maka Hak Akses user dijabarkan pada TABEL II HAK AKSES USER.

TABEL II

\begin{tabular}{|c|l|l|}
\multicolumn{4}{c|}{ HAK AKSES USER } \\
\hline No & \multicolumn{1}{|c|}{ User Sistem } & \multicolumn{1}{c|}{ Hak Akses } \\
\hline \multirow{2}{*}{1.} & $\begin{array}{l}\text { Operator Debug } \\
\text { Manager }(L I)\end{array}$ & $\begin{array}{l}\text { F001, F002, F003, F004, F005, } \\
\text { F008, F009, F010, F011 }\end{array}$ \\
\hline \multirow{2}{*}{2.} & $\begin{array}{l}\text { Teknisi Debug } \\
\text { Manager }\end{array}$ & $\begin{array}{l}\text { F001, F002, F006, F007, F009, } \\
\text { F011 }\end{array}$ \\
\hline
\end{tabular}

C. Perancangan Sistem

1) Use Case

Digunakan untuk menggambarkan fungsionalitas yang diharapkan dari sebuah system.

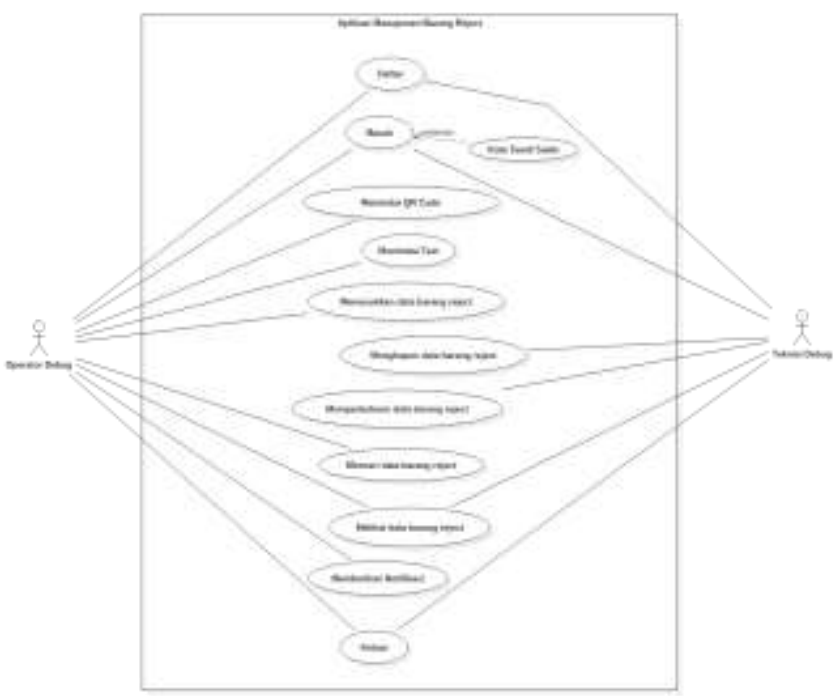

Gbr. 3 Use Case Diagram

2) Sequence Diagram

Sequence Diagram menjelaskan interaksi antar objek berdasarkan urutan waktu atau tahapan yang perlu dilakukan oleh user. Sequence Diagram diperlihatkan pada $\mathrm{Gbr} 4, \mathrm{Gbr}$ 5, Gbr 6, Gbr 7, Gbr 8, Gbr 9, dan Gbr 10.

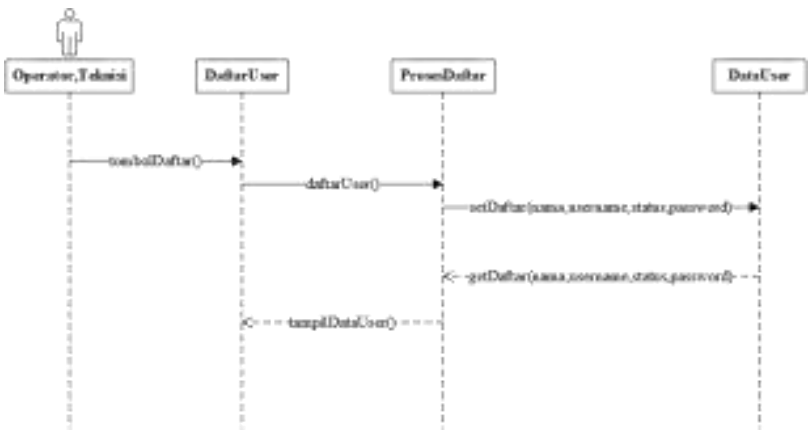

Gbr. 4 Sequence Diagram Daftar

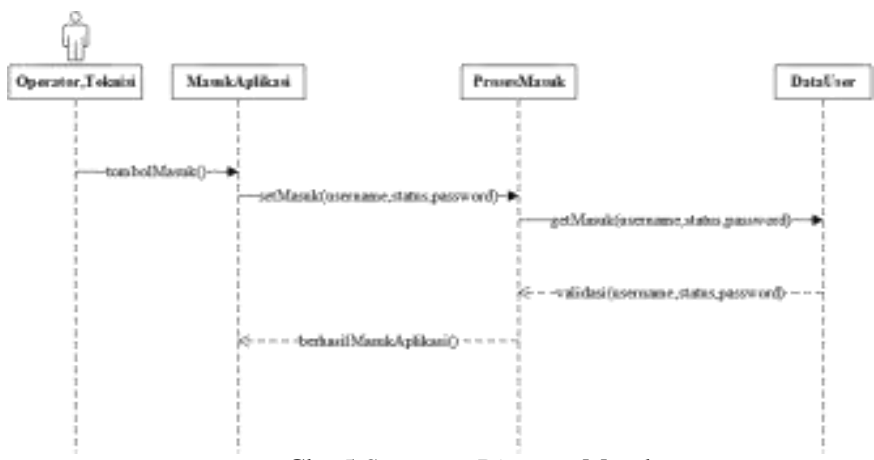

Gbr. 5 Sequence Diagram Masuk

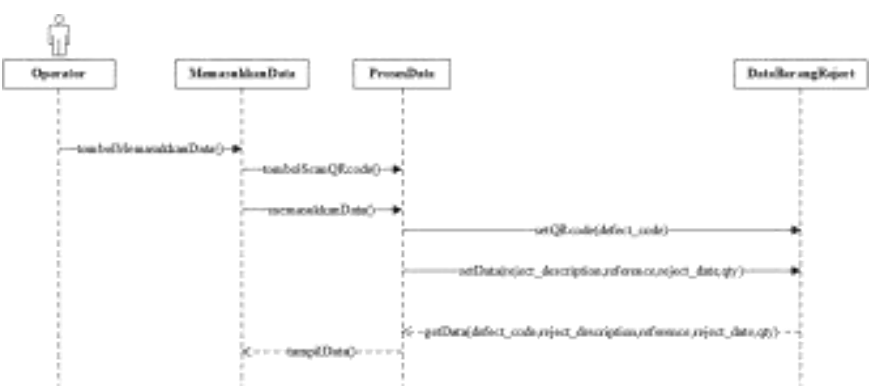

Gbr. 6 Sequence Diagram Memasukkan Data

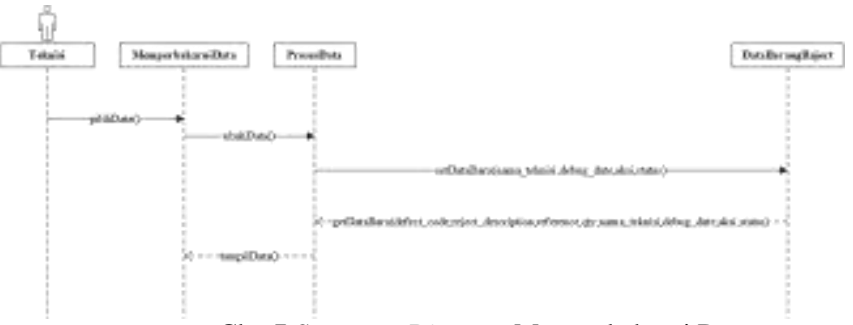

Gbr. 7 Sequence Diagram Memperbaharui Data

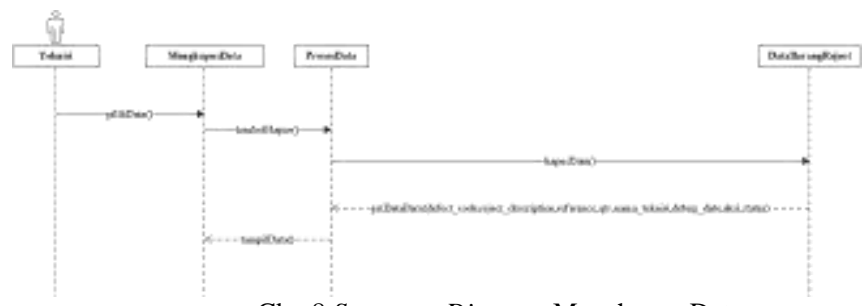

Gbr. 8 Sequence Diagram Menghapus Data

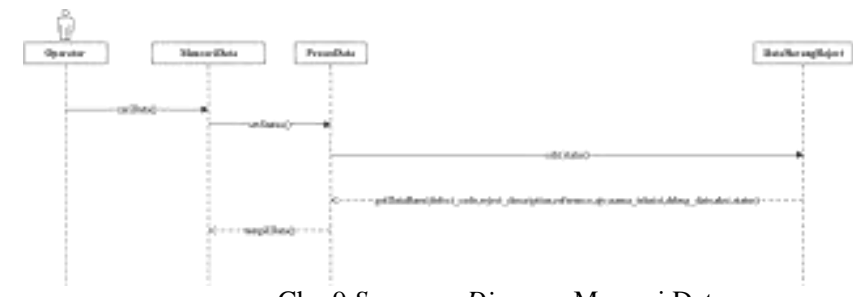

Gbr. 9 Sequence Diagram Mencari Data

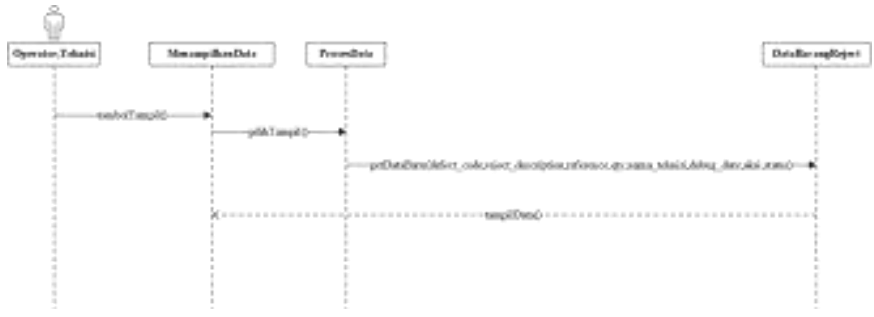

Gbr. 10 Sequence Diagram Melihat Data 


\section{3) ERD (Entuty Relationship Diagram)}

Digunakan untuk memodelkan data yang nantinya akan dikembangkan menjadi database.

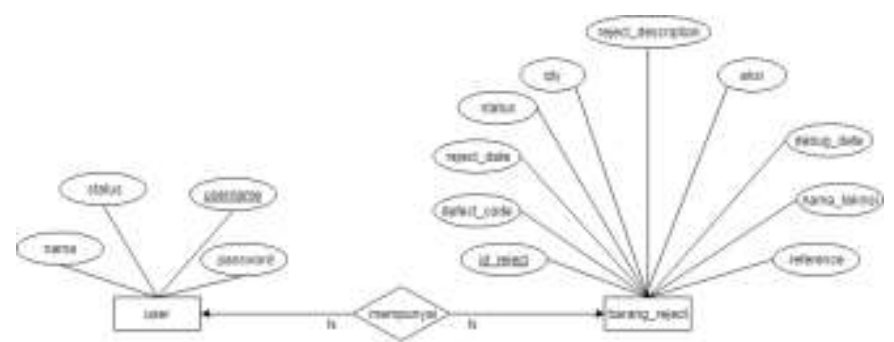

Gbr. 11 ERD

\section{4) Class Diagram}

Digunakan untuk menampilkan kelas-kelas maupun paketpaket yang ada pada suatu system.

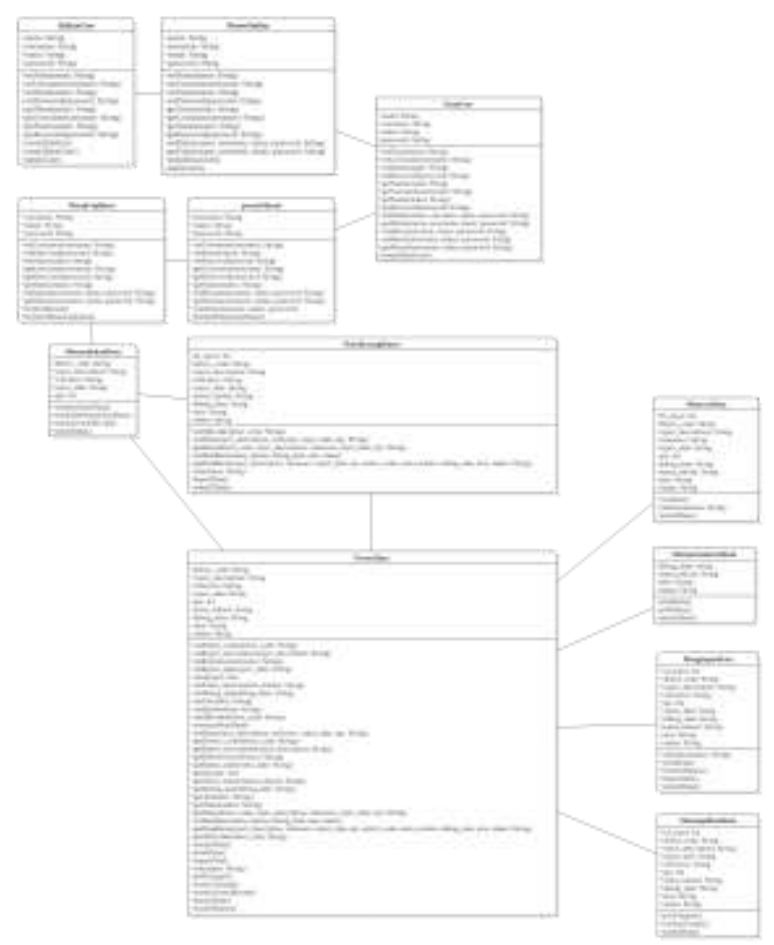

Gbr. 12 Class Diagram

\section{Doftor:Akun}

Nama

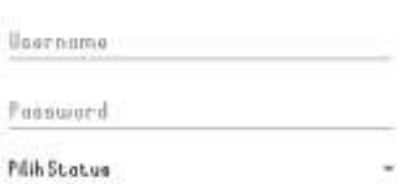

Бөтा
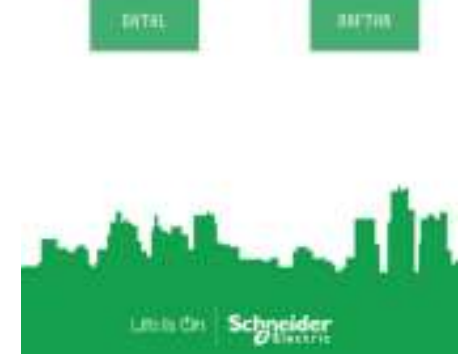

Gbr. 13 Menu Daftar Akun User Baru

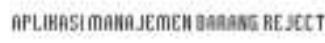

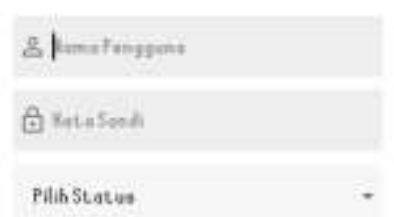

जirtin
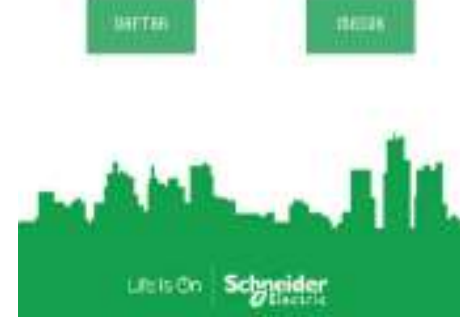

Gbr. 14 Menu Masuk Aplikasi

\section{Implementasi}

Setelah perancangan sistem dilakukan, maka pengimplementasian sistem adalah tahapan selanjutnya dalam membangun Aplikasi Manajemen Barang Reject yang dapat dilihat pada Gbr 13, Gbr 14, Gbr 15, Gbr 16, dan Gbr 17. 


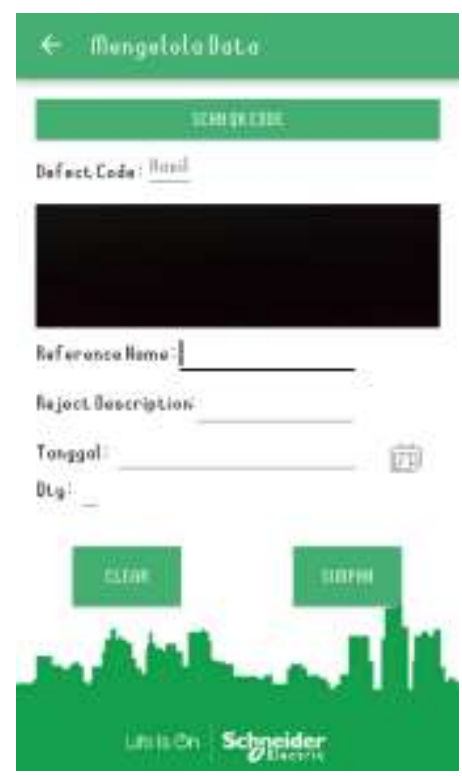

Gbr. 15 Menu Memasukkan Data

\section{\& Purbahacui Datia Barang Rojuct}

Bhejete: 3

Tanggal Nabogi Hemiz, 20 September 2018 fit

Username: heidy

fikei finiahprablem

Stotue: Clage

\section{$\operatorname{mis}$}

\section{inat}

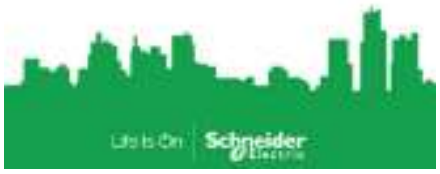

Gbr. 16 Menu Memperbaharui \& Menghapus Data

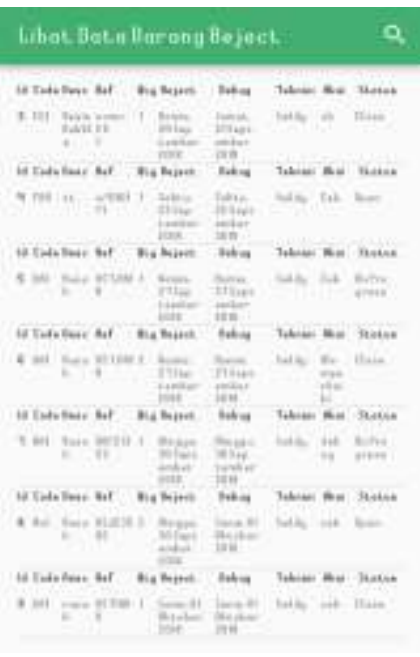

Gbr 17. Menu Melihat dan Mencari Data

\section{E. Pengujian}

Proses pengujian pada aplikasi manajemen barang reject berbasis android di PT. Schneider Electric Manufacturing Batam dilakukan dengan pengujian Black Box, yang mengutamakan pengujian terhadap kebutuhan fungsional dari suatu program dengan tujuan untuk mencari kesalahan fungsi dan memperbaikinya. Pengujian ini dilakukan oleh beberapa orang dengan memberikan sejumlah inputan kedalam aplikasi.

Adapun pengujian yang dilakukan terhadap beberapa fungsionalitas yang akan diuji, antara lain:

- Operator dan teknisi debug dapat mendaftar akun di aplikasi

- Operator dan teknisi debug dapat masuk ke aplikasi

- Operator debug dapat memindai QR code

- Operator debug dapat memindai text

- Operator debug dapat memasukkan data barang reject

- Operator dapat memberikan Notifikasi

- Teknisi debug dapat memperbaharui data barang reject

TABEL III

Hasil PENGUJian BLACK BOX PADA MENU DAFTAR

\begin{tabular}{|c|c|c|c|c|}
\hline Pengguna & $\begin{array}{l}\text { Skenario Uji } \\
\end{array}$ & $\begin{array}{l}\text { Data Uji } \\
\end{array}$ & Hasil yang diharapkan & Hasil Pengujian \\
\hline \multirow{5}{*}{ Operator, Teknisi } & \multirow{5}{*}{$\begin{array}{l}1 \text { Pengguna memasukkan } \\
\text { Nama } \\
2 \text { Pengguna memasukkan } \\
\text { Username } \\
3 \text { Pengguna memasukkan } \\
\text { Password } \\
4 \text { Pengguna memilih Status } \\
\text { User "operator" atau } \\
\text { "teknisi" } \\
5 \text { Pengguna memilih tombol } \\
\text { Daftar }\end{array}$} & $\begin{array}{l}\text { Nama: niken } \\
\text { Username: niken@sch.com } \\
\text { Password: niken } \\
\text { Status : operator }\end{array}$ & $\begin{array}{l}\text { Berhasil mendaftar user } \\
\text { baru }\end{array}$ & Sesuai Harapan \\
\hline & & $\begin{array}{l}\text { Nama: [kosong] } \\
\text { Username: niken@ sch.com } \\
\text { Password: niken } \\
\text { Status : operator }\end{array}$ & $\begin{array}{l}\text { Muncul pesan kesalahan, } \\
\text { gagal mendaftarkan user }\end{array}$ & Sesuai Harapan \\
\hline & & $\begin{array}{l}\text { Nama: niken } \\
\text { Username: [kosong] } \\
\text { Password: niken } \\
\text { Status : operator }\end{array}$ & $\begin{array}{l}\text { Muncul pesan kesalahan, } \\
\text { gagal mendaftarkan user }\end{array}$ & Sesuai Harapan \\
\hline & & $\begin{array}{l}\text { Nama: niken } \\
\text { Username: niken@sch.com } \\
\text { Password: niken } \\
\text { Status : [-] }\end{array}$ & $\begin{array}{l}\text { Muncul pesan kesalahan, } \\
\text { gagal mendaftarkan user }\end{array}$ & Sesuai Harapan \\
\hline & & $\begin{array}{l}\text { Nama: niken } \\
\text { Username: niken@sch.com } \\
\text { Password: [kosong] } \\
\text { Status : operator }\end{array}$ & $\begin{array}{l}\text { Muncul pesan kesalahan, } \\
\text { gagal mendaftarkan user }\end{array}$ & Sesuai Harapan \\
\hline
\end{tabular}


- Teknisi debug dapat menghapus data barang reject

- $\quad$ operator dan teknisi debug dapat melihat data barang reject

- Operator debug dapat mencari data barang reject

- Operator dan teknisi debug dapat keluar dari aplikasi

Hasil pengujian menunjukan bahwa aplikasi barang reject berbasis android ini berjalan sesuai dengan yang telah dirancang sebelumnya. Berikut TABEL III hasil pengujian black box pada menu daftar akun user baru.

\section{KESIMPULAN}

Setelah melalui tahap perancangan, implementasi dan pengujian aplikasi manajemen barang reject berbasis android di PT. Schneider Electric Manufacturing Batam, maka kesimpulannya adalah telah dibangun sebuah aplikasi manajemen barang reject berbasis android. Sesuai hasil pengimplementasian aplikasi manajemen barang reject berbasis android, aplikasi berhasil memindai $Q R$ Code, Text dan dapat memberikan notifikasi serta menampilkan data barang reject. Setelah dilakukannya pengujian Aplikasi, maka perlu dilakukan sosialisasi mengenai penggunaan aplikasi manajemen barang reject kepada operator dan teknisi

Demi mencapai kesempurnaan Aplikasi ini, penulis menyampaikan beberapa saran kepada pengembang selanjutnya, antara lain sebaiknya menambahkan fitur mengunduh data yang juga dapat dicetak dan dijadikan pelaporan fisik. Sebaiknya menggunakan database yang dapat menyimpan data lebih banyak, seperti SQL Server dan menambahkan fitur menampilkan data dalam bentuk diagram

\section{DAFTAR PUSTAKA}

[1] Fathonah, Trisma Nur, Bunyamin \& Cahyana, R., "Pengembangan Fitur Retur dari Sistem Informasi Persediaan Barang", ISSN, vol.15, no.1, pp.1-7.2016.

[2] Sepantri, Rino., "Sistem Informasi Pengolahan Barang Return pada PT. LGEIN Cabang Semarang", pp.1-12.2007.

[3] Sukamdana, Boogie, "Perancangan Sistem Informasi Inventory Berbasis Web pada PT. Citra Gemilang Prima", pp.1-14.2011.

[4] Yudhanto, Yudha \& Ardhi Wijayanto.2017, Mudah Membuat dan Berbisnis Aplikasi Android dengan Android Studio.Jakarta: PT. ELEX MEDIA KOMPUTINDO

[5] Firly, Nadia. 2018.Create Your Own Android Application. Jakarta: PT. ELEX MEDIA KOMPUTINDO

[6] Kumar, Dixit Prasanna 2014 Android India: VIKAS PUBLISHING HOUSE PVT LTD

[7] Anhar. 2010. Panduan Menguasai PHP \& MySQL secara Otodidak. Jakarta: mediakita

[8] Solichin, A. 2016. "Pemrograman Web dengan PHP dan MySQL".

[9] Yurindra. 2017. Software Engineering. Yogyakarta: Deepublish

[10] Nugroho, Adi. 2009. Rekayasa Perangkat Lunak Menggunakan UML dan JAVA.Yogyakarta: C.V ANDI OFFSET 